Gallois, R. W. 2007. Landslide on the Devon coast. Q. J. Eng. Geol. \& Hydro., Vol. 40, 29-34.

\title{
A recent landslide on the east Devon coast, U.K.
}

R. W. Gallois

Quaternary Journal of Engineering Geology and Hydrogeology, Vol. 40, 29-34.

\section{Introduction}

The largest landslides on the south coast of England are those associated with failure surfaces in montmorillonite-rich mudstones close to the base of the Gault Formation (mid Cretaceous).

Those at Folkestone, Sussex (Trenter \& Warren, 1996), Ventnor, Isle of Wight (Hutchinson, 2001) and Black Ven, west Dorset (Brunsden, 2002) are among the largest active landslide systems in the UK. Westwards from Dorset, the Gault facies of the Albian Stage is replaced on the east Devon coast by sandstones and sandy calcarenites of the Upper Greensand Formation. These are mostly moderately strong rocks that crop out in almost continuous, precipitous cliffs between Sidmouth and the county boundary at Lyme Regis. They are a major component of the landslide debris, but the formation itself has not previously been shown to have initiated a failure. For example, the extensive Bindon landslide [SY 277 895] near Axmouth, which incorporates large masses of Upper Greensand, was attributed to failure surfaces in the Gault (Conybeare et al., 1840). However, that formation has not been recorded in a coastal section west of Lyme Regis.

Joint/bedding-bounded toppling failures have been observed from time to time in the highest, more massive part of the Upper Greensand along the east Devon coast. The most recent of these occurred after a prolonged period of wet weather in 2001 when a single block of about 3000 tonnes in the highest part of the Upper Greensand fell over $120 \mathrm{~m}$ from the western end of Higher Dunscombe Cliff, Salcombe Regis [SY 150 878] and broke up on the beach. A similar mechanism has until now seemed to be the most likely explanation to account for the accumulations of angular blocks of Upper Greensand up to several hundred tonnes in weight that are common in the intertidal area between Beer Head and Sidmouth (Fig.1).

A recent landslide involving a large volume of Upper Greensand, the largest on the east Devon coast for about 40 years, has enabled the mechanism to be studied in more detail and suggests the toppling assumption to be incorrect for the origin of most of the beach boulders on this part of the coast. 
Gallois, R. W. 2007. Landslide on the Devon coast. Q. J. Eng. Geol. \& Hydro., Vol. 40, 29-34.

\section{Salcombe Regis Landslide, 2006}

The landslide occurred in the early hours of January $4^{\text {th }} 2006$ at the western end of Higher Dunscombe Cliff, Salcombe Regis, adjacent to the 2001 toppling failure (Fig. 2). No person or property was involved, but a section of about $150 \mathrm{~m}$ of the Southwest Coastal Path and an adjacent hedge and fence fell about $160 \mathrm{~m}$ to the beach (Fig. 3). The width of the collapsed mass varied at cliff-top level from about 5 to $20 \mathrm{~m}$. It is estimated that the total mass of the landslide was about 250,000 tonnes. The debris spread out to cover a $200+\mathrm{m}$ width of the beach and intertidal area (Fig. 4A). Individual blocks up to $5 \times 5 \times 4 \mathrm{~m}$ of the more durable lithologies came to rest up to $150 \mathrm{~m}$ beyond the foot of the cliff, below the low-water level of Spring tides (Fig. 4B).

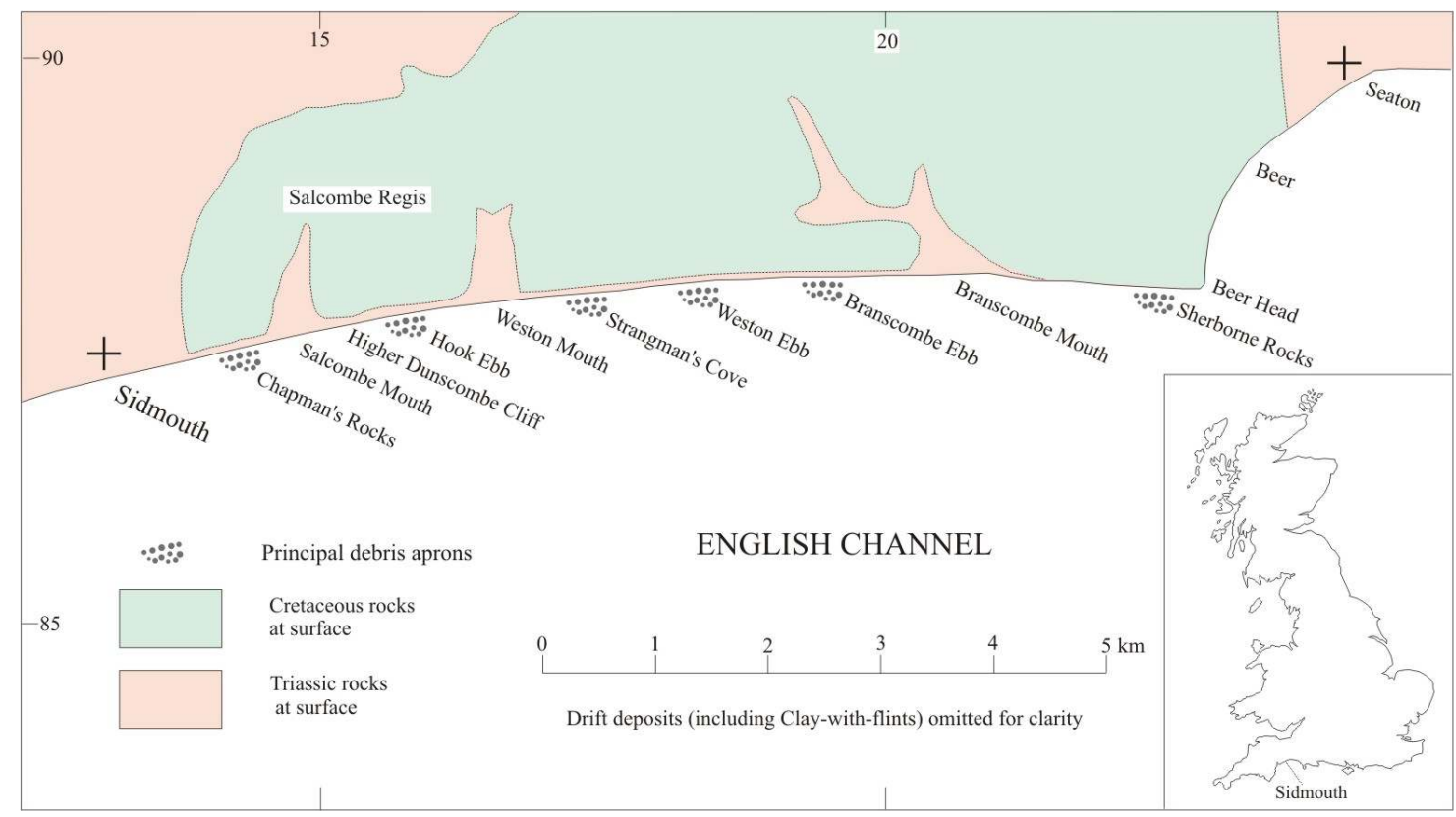

Figure 1. Geological sketch map of the coastal area between Sidmouth and Seaton, east Devon.

The cliffs between the Axe Valley and Sidmouth can be divided into two parts (Fig. 5). The lower cliffs (mostly at $40^{\circ}$ to $85^{\circ}$ ) are composed of well-jointed, moderately strong Triassic mudstones and siltstones of the Mercia Mudstone Group (Edwards \& Gallois, 2004). 
Gallois, R. W. 2007. Landslide on the Devon coast. Q. J. Eng. Geol. \& Hydro., Vol. 40, 29-34.

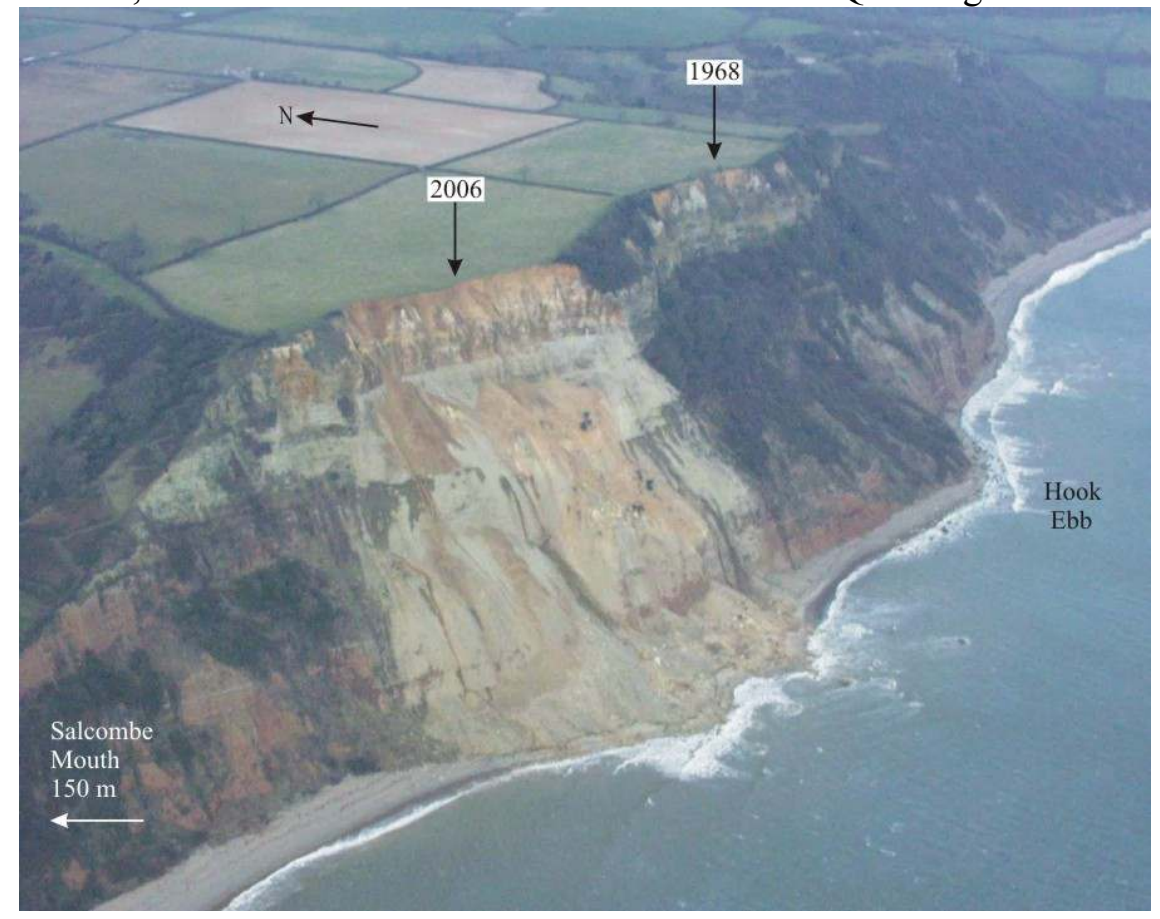

Figure 2. Salcombe Regis landslide, January $4^{\text {th }} 2006$; viewed from the south west. Photo courtesy Maritime and Coastguard Agency.

The mudstones are overlain with marked unconformity by sandstones and calcarenites of the Cretaceous Upper Greensand that form spectacular cliffs (mostly at $75^{\circ}$ to vertical). In the area at and adjacent to the 2006 landslide, a more fluvial formation (the Dunscombe Mudstone) in the middle part of the Mercia Mudstone Group contains beds of laminated sepiolite-rich mudstone (Jeans, 1978) that contribute to rotational landslides. These beds are present close below the unconformity in the eastern part of the 2006 landslide, but are not thought to contribute to it. The only Triassic material present in the landslide debris were small pieces of red mudstone (Sidmouth Mudstone Formation) presumably dislodged from the lower cliff by falling blocks. In contrast, the residual debris from an adjacent landslide that took place in 1968 contains appreciable amounts of Dunscombe Mudstone (Jeans, 1978).

The distribution of the Upper Greensand lithologies in the 2006 debris cone is in roughly the same stratigraphical order as that in the cliffs. The succession exposed in Higher Dunscombe Cliff can be divided on gross lithology into six stratigraphically controlled units that give rise to a characteristic cliff profile (Fig. 6A). In the lowest part, weakly calcareously cemented permeable sandstones of the 'lower' Foxmould Member are prone to dissolution (Fig. 6B). 
Gallois, R. W. 2007. Landslide on the Devon coast. Q. J. Eng. Geol. \& Hydro., Vol. 40, 29-34.

The lowest 1-2 m contain rare thin (up to $20 \mathrm{~mm}$ thick), lenticular beds of sandy clay in which the clay content is largely montmorillonite (pers comm. C.V. Jeans, 2006). The 'upper' Foxmould also consists of weakly cemented sandstones but, in addition, contains tabular and lenticular beds of well-cemented calcareous sandstone at numerous levels.

The overlying Whitecliff Chert and Bindon Sandstone members (Gallois, 2004), collectively referred to as the 'Chert Beds' by earlier authors, consist of strong, mostly massive calcareous sandstones and sandy calcarenites. They form vertical and near-vertical cliffs with well-defined bedding and joint partings that give rise to toppling failures. At the base of each member, a glauconite-rich bed forms a plane of weakness and a notch in the cliffs. The lower part of the Whitecliff Chert at this locality consists of strongly cemented calcareous sandstones with up to six hardground surfaces underlain by dense nodular sandy limestones.

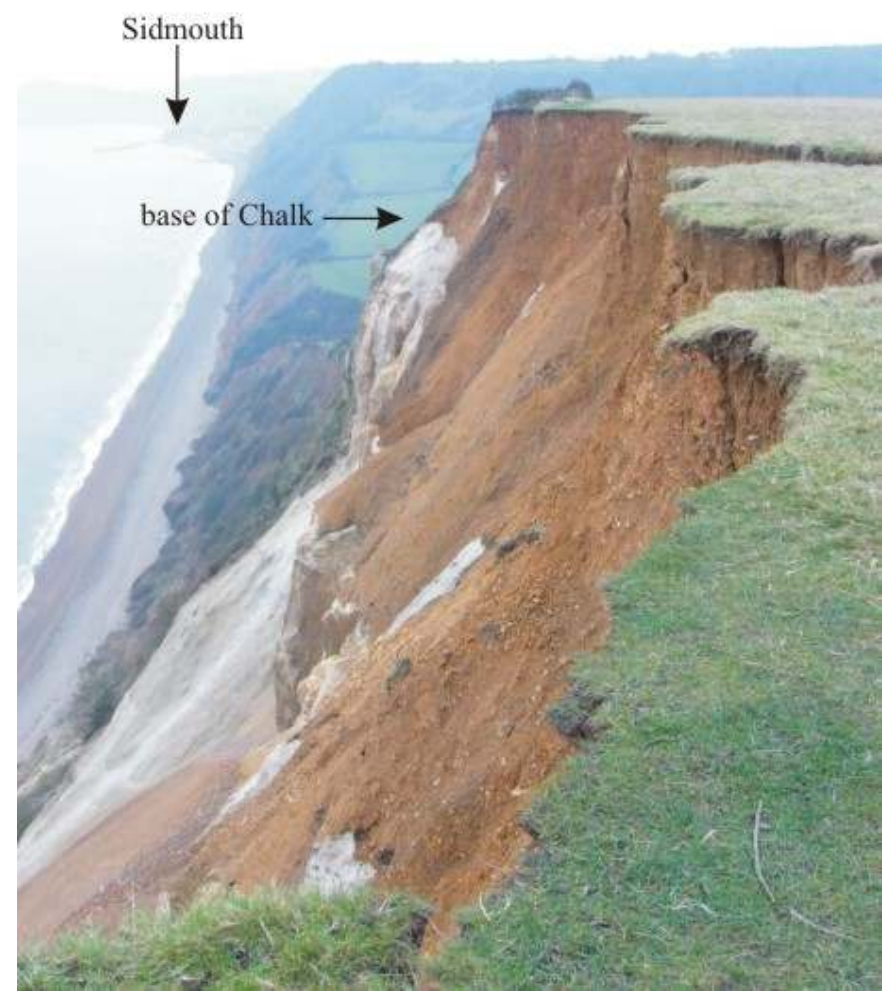

Figure 3. View west from the coastal path. The Clay-with-flints, here composed largely of angular chert and flint clasts in a sand matrix, rests on an irregular, solution-pocketed chalk surface. 
Gallois, R. W. 2007. Landslide on the Devon coast. Q. J. Eng. Geol. \& Hydro., Vol. 40, 29-34.
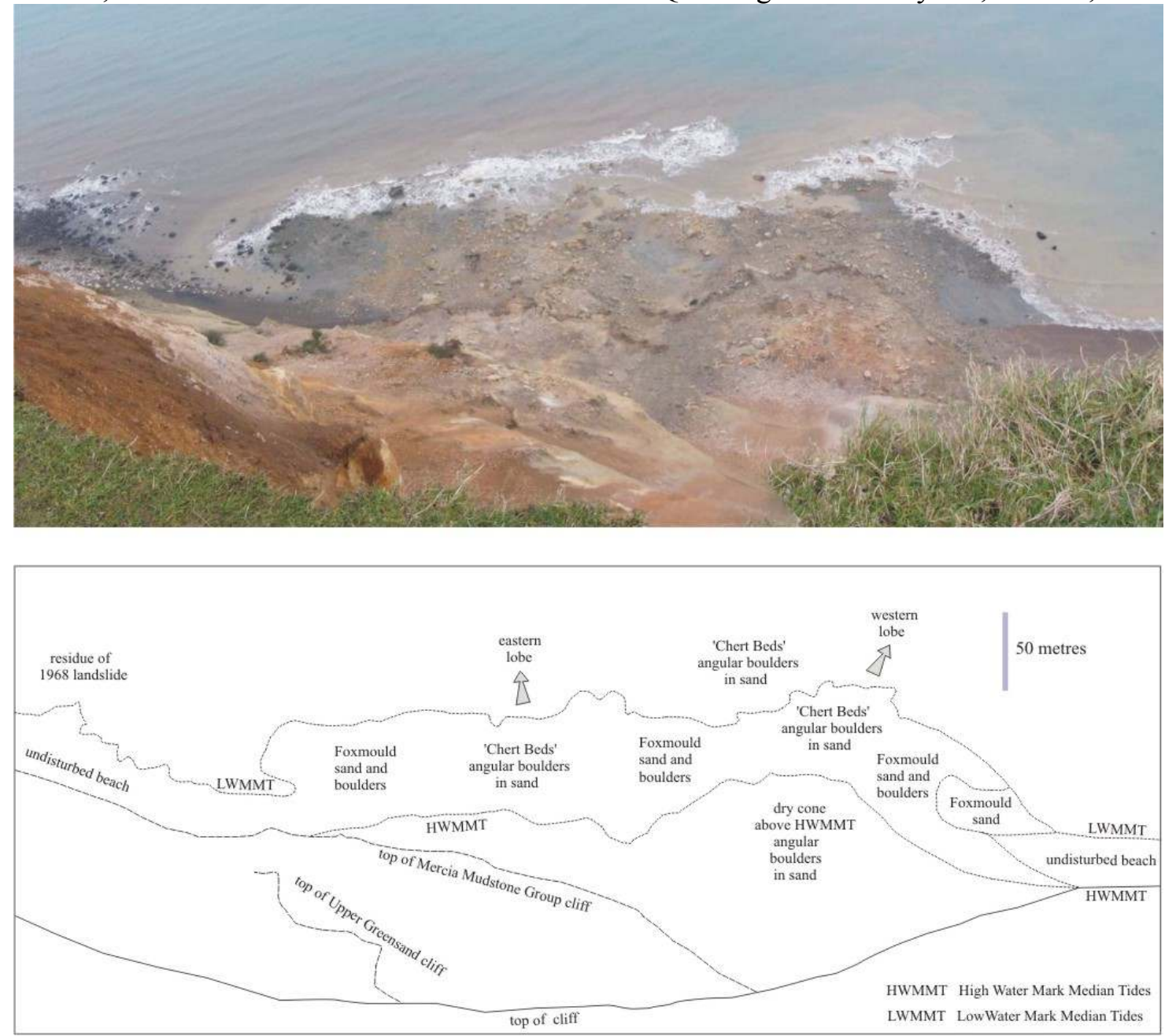

Figure 4. A \& B The debris apron viewed from the cliff top. The distribution of the Upper Greensand Formation components indicates that the failure surface was at or close to the base of the formation.

Five to six beds with cherts up to $0.4 \mathrm{~m}$-thick are present in the lower part of the member. The upper part of the member consists of massive calcareous sandstones with numerous horizons of calcareous concretions. The Bindon Sandstone consists largely of calcareous sandstones and sandy calcarenites. The more massive beds (Fig. 7) were extensively worked nearby in medieval times under the name 'Salcombe Stone'. They provided the exterior stone for Exeter Cathedral and most of the local churches. The Beer Head Limestone at the base of the Chalk Group is a 2$\mathrm{m}$ thick, massive bioclastic limestone. The overlying beds are weak chalks that become gravelsized rubble in the landslide debris. 
Gallois, R. W. 2007. Landslide on the Devon coast. Q. J. Eng. Geol. \& Hydro., Vol. 40, 29-34.

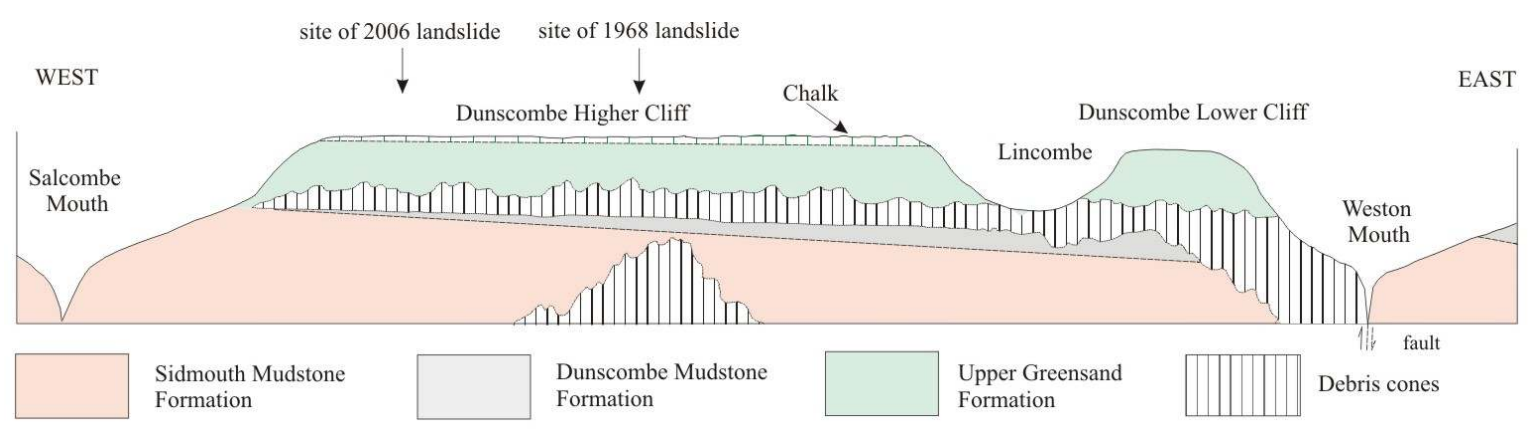

Figure 5. Geological sketch section of the cliffs between Salcombe Mouth and Weston Mouth showing the westward overstep of the Cretaceous Upper Greensand across the Triassic Mercia Mudstone Group.

Within the landslide debris, the larger cuboidal blocks (up to $5 \times 5 \times 4 \mathrm{~m}$ ) are composed of either joint/bedding-bounded hardground-rich 'lower' Whitecliff Chert or 'Salcombe Stone'. Their angularity and distribution suggest that they were carried to their present positions within a matrix-supported debris flow. A similar origin is assumed for slabs of 'upper' Whitecliff Chert up to $9 \times 5 \times 2$ m-thick that are bounded by glauconite-rich bedding surfaces. These are right-wayup: some have snapped into pieces in the intertidal area when the matrix was washed away.
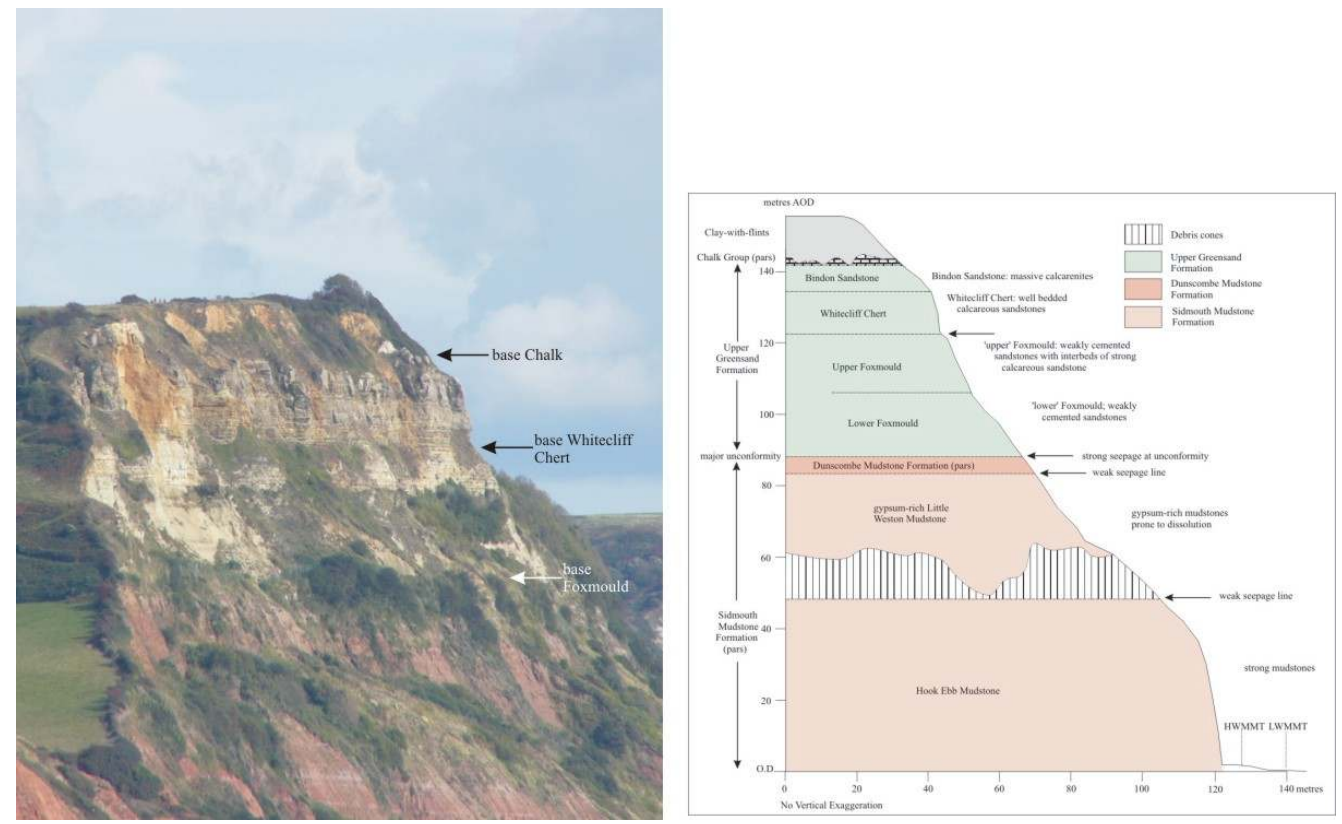

Figure 6. A The upper part of Higher Dunscombe Cliff at the landslide site viewed from the west in 2005. B Cliff profile in the central part of the landslip area prior to the failure. 
Gallois, R. W. 2007. Landslide on the Devon coast. Q. J. Eng. Geol. \& Hydro., Vol. 40, 29-34.

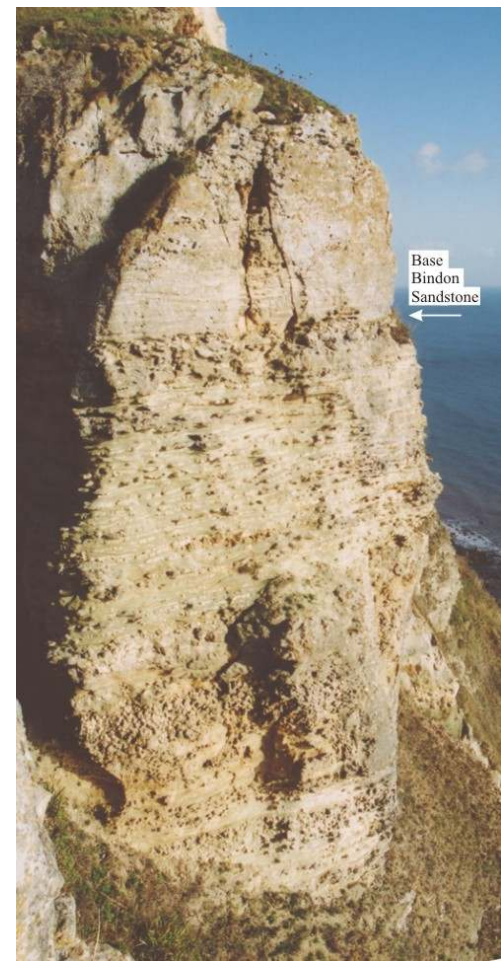

Figure 7. The sandstones and calcarenites of the Whitecliff Chert and Bindon Sandstone form vertical and near vertical cliffs at Higher Dunscombe Cliff. A network of vertical joints and welldefined bedding discontinuities make these beds prone to toppling failure.

Most of the fines from the debris cone in the intertidal area were removed by the sea within a few tidal cycles. Four weeks after the landslide, the weaker lithologies had been reduced to rounded cobbles and boulders. Only the larger blocks of Whitecliff Chert and Bindon Sandstone had retained their angular shapes (Fig. 8). Similar blocks in the residual debris from earlier landslides suggest that they become encrusted by Mytilus and other organisms within 1 to 2 years and suffer little further erosion. The matrix-supported nature of the unweathered debris cone can be observed in the supra-tidal part of the 2006 landslide and in cliff sections at the foot of the 1968 landslide.

\section{Failure mechanism}

The distribution of the debris in the intertidal area strongly suggests that the principal failure surface was at or close above the unconformity at the base of the Upper Greensand, probably along a thin (10 to $20 \mathrm{~mm}$ thick) montmorillonite-rich bed. The oldest strata, the soft glauconitic sands of the 'lower' Foxmould, appear to underlie the whole of the debris cone. Immediately 
Gallois, R. W. 2007. Landslide on the Devon coast. Q. J. Eng. Geol. \& Hydro., Vol. 40, 29-34. after failure the partially decalcified Foxmould collapsed and triggered bedding- and jointbounded failures in the overlying beds. This resulted in a debris flow containing blocks of 'Chert Beds' within a Foxmould-sand matrix. Successively younger parts of the succession are now concentrated in two lobes (Fig.4A and B) that represent the coarse-fraction residues of separate debris flows. The failure mechanism proposed here has not previously been reported from the Upper Greensand, and could be considered as the causal mechanism for all the large debris aprons in the intertidal area on the east Devon coast between Seaton and Sidmouth.

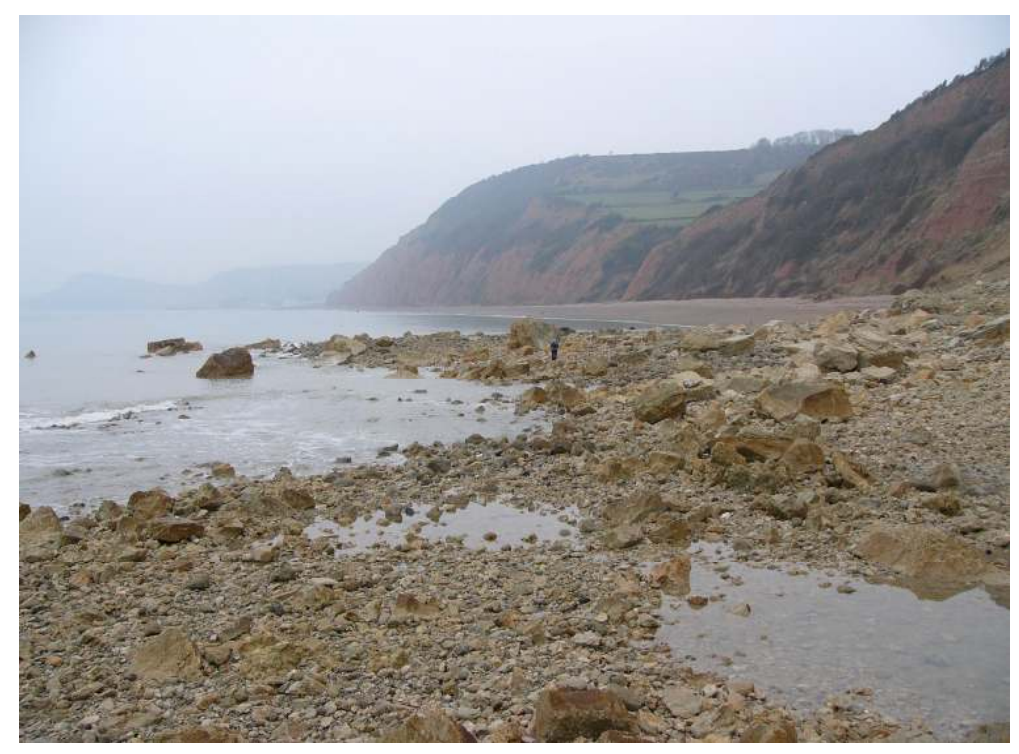

Figure 8. The 2006 debris apron at low Spring tide, viewed from the east four weeks after the landslide. The finer grained materials have been dispersed and all except the hardest lithologies reduced to rounded cobbles and boulders.

\section{References}

BRUNSDEN, D. 2002. Geomorphological roulette for engineers and planners: some insights into an old game. Quarterly Journal of Engineering Geology and Hydrogeology, 35, 101-142. Conybeare, W.D., Dawson, W., Buckland, M. \& Buckland, W. 1840. Ten Plates, comprising a plan, sections, and views, representing the changes produced on the Coast of East Devon, between Axmouth and Lyme Regis, by the Subsidence of the Land and Elevation of the bottom of the Sea, on the 26th December, 1839, and 3rd February, 1840. Oblong, London. EDWARDS, R.A. \& GALLOIS, R.W. 2004. The geology of the Sidmouth district: a brief description of Sheet 326 ad 340 Sidmouth. Sheet Explanation of the British Geological Survey. British Geological Survey, Keyworth. 
Gallois, R. W. 2007. Landslide on the Devon coast. Q. J. Eng. Geol. \& Hydro., Vol. 40, 29-34. GALLOIS, R.W. 2004. The stratigraphy of the Upper Greensand Formation (Cretaceous) of southwest England. Geoscience in south-west England, 11, 21-29.

HUTCHINSON, J.N. 2001. Reading the ground: morphology and geology in site appraisal. Quarterly Journal of Engineering Geology and Hydrogeology, 34, 157-168.

JEAns, C.V. 1978. The origin of the Triassic clay assemblages of Europe with special reference to the Keuper Marl and Rhaetic of parts of England. Philosophical Transactions of the Royal Society of London, Series A, 289, 549-639.

Trenter, N.A. \& WARREN, C.D. 1996. Further investigations at the Folkestone Warren landslide. Geotechnique, 46, 589-620. 